\title{
Pharmaciana
}

Vol. 8, No.1, May 2018, Page. 1-10

ISSN: 2088 4559; e-ISSN: 24770256

\section{Chemometrics-assisted spectrophotometry for simultaneous determination of sodium benzoate and citric acid in beverage products}

\author{
Ganjar Wahyu Rahardian, Sausa Monica, Hendri Wasito*, Sri Sutji Susilowati \\ Department of Pharmacy, Faculty of Health Sciences, Jenderal Soedirman University \\ Jln. Dr. Soeparno, Kampus Unsoed Karangwangkal, Purwokerto, Central Java, Indonesia
}

Submitted: 10-07-2017 Reviewed: 22-03-2017 Accepted: 24-04-2018

\begin{abstract}
The development and validation of chemometrics-assisted spectrophotometry have been successfully performed for determination of sodium benzoate and citric acid that have overlapping of ultra violet absorption spectra. The study aimed to develop, validate, and apply spectrophotometric method with chemometrics approach for determination of both compounds in beverage products simultaneously. The analytical method was performed by making a calibration model using 16 training sets and 10 test sets of mixed solution followed by absorbance measurenment at wavelength of $190 \mathrm{~nm}$ up to $400 \mathrm{~nm}$. In addition, the absorbance data was processed by multivariate calibration models of principal component regression (PCR) and partial least square-1 (PLS-1) and validated internally and externally to obtain optimum model. Validation of analytical methods was done by evaluating some parameters such as linearity and ranges, accuracy, precision, detection limits and quantification limits. The results showed that the optimum wavelength was $235 \mathrm{~nm}$ to $250 \mathrm{~nm}$ for sodium benzoate and 220 $\mathrm{nm}$ to $240 \mathrm{~nm}$ for citric acid with the selected optimum principal components (PCs) value were 6 (PCR) and 4 (PLS-1) for sodium benzoate and PCs 2 (PCR and PLS-1) for citric acid. The parameters of the analytical method validation developed were suitable and the analytical methods could be applied for the determination of the sodium benzoate and citric acid contents simultaneously in the beverage products.
\end{abstract}

Keywords: spectrophotometry, chemometrics, validation, sodium benzoate, citric acid

\footnotetext{
Corresponding author:

Hendri Wasito

Department of Pharmacy, Faculty of Health Sciences, Jenderal Soedirman University

Jln. Dr. Soeparno, Kampus Unsoed Karangwangkal, Purwokerto, Central Java

Email: hendri.apt@gmail.com
} 


\section{INTRODUCTION}

Sodium benzoate and citric acid (Figure 1) are food additives which are often combined as preservatives and regulators of acidity in beverage products (Brima and Abbas, 2014; Ciriminna et al., 2017; Penniston et al., 2008). The use of both compounds excessively can cause various side effects such as asthma, urticaria, hyperactivity, renal and hepatic disorders, and tooth enamel damage (Abd-Al Gadir et al., 2009; Chen et al., 2015, 2014; Keshavarz et al., 2012; Ren et al., 2009; Shahmohammadi et al., 2016; Shu et al., 2016). Several methods have been used in the analysis of both compounds in beverage products for instance high performance liquid chromatography (HPLC) and mass spectrometry (MS) (Ayorinde et al., 2003; Grembecka et al., 2014).<smiles>O=C(O[Na])c1ccccc1</smiles><smiles>O=C(O)CC(O)(CC(=O)O)C(=O)O</smiles>

(B)

Figure 1. Chemical Structure (A) Sodium Benzoate and (B) Citric Acid

Simultaneous analysis of both compounds using conventional spectrophotometry cannot be performed with a good result because sodium benzoate and citric acid have overlapping absorbance UV spectra (Wasito and Phechkrajang, 2015). Spectrophotometry with chemometrics approach was one of the strategies to overcome the problem (Phechkrajang et al., 2011; Sratthaphut and Ruttanakorn, 2015). Overlapping UV absorbance data from measurements of compound mixtures with spectrophotometry could be used and processed by chemometric models for the determination of each compound simultaneously (El-Zaher et al., 2017; Patel et al., 2014; Wasito et al., 2018).

Chemometric is a subject of chemistry that using mathematical and statistical approaches to design optimum experimental procedures, but it can also be used to optimize and retrieve relevant chemical information from complex chemical data analysis (Geladi, 2003; Marini, 2016; Varmuza et al., 2014). Principal component analysis (PCA) and Partial Least Squares (PLS-1) is a kind of chemometric analysis with multivariate calibration calculation to form a model that can be used to predict and determine the concentration of several compounds simultaneously (Brereton, 2000).

To the best of our knowledge, publications on the use of spectrophotometry with the chemometrics approach of PCR and PLS-1 models for determine of sodium benzoate and citric acid in beverage products have never been done. Therefore, the purpose of this study was to develop, validate, and apply spectrophotometric methods with chemometrics (PCR and PLS-1) approaches for simultaneous determination of sodium benzoate and citric acid concentrations in beverage products.

\section{MATERIALS AND METHODS \\ Materials}

The instruments that used were double beam UV-VIS 1800 spectrophotometer (Shimadzu Corporation, Kyoto, Jepang) with $1 \mathrm{~cm}$ quartz quvet container, multivariate analysis software

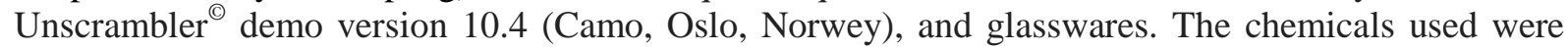
benzoic acid (Merck, Darmstadt, Germany), citric acid (Merck, Darmstadt, Germany), 37\% $\mathrm{HCl}$ (Merck, Darmstadt, Germany), and distilled water. The samples used were energy drink beverage products obtained from the market in Purwokerto that contained food additives in the form of sodium benzoate and citric acid that was stated on the packaging label.

\section{Preparation of standard stock solution and working standard solution mixture}

Preparation of standard solution was made by carefully weighing of benzoate acid standard compound which in subsequent levels converted to sodium benzoate concentration and citric acid 
standard compound then dissolved into $0.1 \mathrm{~N} \mathrm{HCl}$ to obtain each stock solution of sodium benzoate and citric acid with a concentration of $500.0 \mu \mathrm{g} / \mathrm{mL}$ and $10,000.0 \mu \mathrm{g} / \mathrm{mL}$. The standard solution mixtures were prepared by mixing each solution and diluted with $0.1 \mathrm{~N} \mathrm{HCl}$ to obtain the desired concentration.

\section{Spectra measurement of UV absorbance profile}

The absorbance profile at wavelengths of $190 \mathrm{~nm}$ to $400 \mathrm{~nm}$ was measured using a spectrophotometer for each stock solution. The concentration used was $5.0 \mu \mathrm{g} / \mathrm{mL}$ sodium benzoate and $550.0 \mu \mathrm{g} / \mathrm{mL}$ citric acid using a $0.1 \mathrm{~N} \mathrm{HCl}$ solution as a blank. The curve between the wavelength and absorbance value obtained from the measurements was made to determine the absorption profile of the two compounds.

\section{Development of chemometric models}

The development of the chemometric models were performed by preparing 16 standard mixed solutions of training sets to construct a model that were made based on central composite design (CCD) calculation with two factors $(\mathrm{k}=2)$ (Bezerra et al., 2008; Esbensen et al., 2004). The training set concentration ranges used was 2.0 to $9.0 \mu \mathrm{g} / \mathrm{mL}$ and 200.0 to $820.0 \mu \mathrm{g} / \mathrm{mL}$ for benzoic acid and citric acid respectively. The concentration range of the test sets were taken at that range and not be used in the training sets composition that randomLy selected. The concentration and composition of the standard solution mixture of the training set and test set were presented in Table I.

The absorbance data measured by spectrophotometry in the training set solution were processed using multivariate analysis of PCR and PLS-1 that were performed by the Unscrambler ${ }^{\odot}$ program to create a calibration model for each compound. Subsequently, the models were optimized by selecting the wavelength and principal component (PC) ranges and validating the model internally with the predicted training sets and external data sets with the test sets prediction data. Leave-one-out cross validation (LOO-CV) was used in internal validation. To know the error in the prediction of chemometric models, root mean squares error of calibration (RMSEC) parameter, root mean squares error of prediction (RMSEP), and coefficient of determination $\left(\mathrm{r}^{2}\right)$ were evaluated (Faber and Kowalski, 1997). In addition, the percentage of recovery and RSD values of the model predictions were evaluated to see the model's ability of predict the determination results.

\section{Validation of spectrophotometric method using chemometrics approach}

Validation of analytical methods was performed by evaluating several analysis parameters such as linearity and range, accuracy, precision, limit of detection (LOD), and limit of quantification (LOQ) according to guidelines of ICH Q2 (R1) (Borman and Elder, 2017). Validation was conducted by measuring the absorbance of the three replicated sample solution with the spectrophotometer, and then the resulting data was processed using the optimum chemometric model to find out the sample measurement results.

The linearity and range assays were evaluated using five concentrations of standard solution mixture with concentration range 2.0 to $13.0 \mu \mathrm{g} / \mathrm{mL}$ for sodium benzoate and 200.0 to $800.0 \mu \mathrm{g} / \mathrm{mL}$ for citric acid. The standard addition method was used for evaluation of accuracy at three concentration levels of $80 \%, 100 \%$, and $120 \%$ with the standard concentrations added successively were $4.0 \mu \mathrm{g} / \mathrm{mL}$; $5.0 \mu \mathrm{g} / \mathrm{mL}$; and $6.0 \mu \mathrm{g} / \mathrm{mL}$ for sodium benzoate and $320.0 \mu \mathrm{g} / \mathrm{mL} ; 400.0 \mu \mathrm{g} / \mathrm{mL}$; and $480.0 \mu \mathrm{g} / \mathrm{mL}$ for citric acid. The accuracy assay was performed by taking $0.1 \mathrm{~mL}$ of the beverage product sample solution and added with a mixture of standard solutions at each concentration level. The precision test was intra-day and inter-day performed using the same sample that was used in accuracy assay. Intraday precision was performed by measuring three replicated solution on the same day while the interday precision was performed on three different days. The detection and quantification limits (LOD and LOQ) were determined based on the standard solution calibration curve. 
Table I. Composition of training set and test set of sample

\begin{tabular}{|c|c|c|c|c|}
\hline \multirow{2}{*}{$\begin{array}{c}\text { Sample } \\
\text { No. }\end{array}$} & \multicolumn{2}{|c|}{ Training set $(\mu \mathrm{g} / \mathrm{mL})$} & \multicolumn{2}{|c|}{ Test set $(\mu \mathrm{g} / \mathrm{mL})$} \\
\hline & Sodium Benzoate & Citric Acid & $\begin{array}{c}\text { Sodium } \\
\text { Benzoate }\end{array}$ & $\begin{array}{l}\text { Citric } \\
\text { Acid }\end{array}$ \\
\hline 1 & 2.6 & 507.5 & 6.8 & 284.2 \\
\hline 2 & 9.1 & 507.5 & 3.2 & 253.8 \\
\hline 3 & 5.8 & 203.0 & 3.6 & 304.5 \\
\hline 4 & 5.8 & 812.0 & 3.9 & 355.3 \\
\hline 5 & 4.5 & 203.0 & 4.4 & 456.8 \\
\hline 6 & 4.5 & 812.0 & 5.2 & 558.3 \\
\hline 7 & 7.1 & 203.0 & 6.5 & 609.0 \\
\hline 8 & 7.1 & 812.0 & 2.9 & 659.8 \\
\hline 9 & 5.8 & 507.5 & 7.8 & 710.5 \\
\hline 10 & 5.8 & 507.5 & 8.4 & 761.3 \\
\hline 11 & 5.8 & 507.5 & & \\
\hline 12 & 5.8 & 507.5 & & \\
\hline 13 & 5.8 & 507.5 & & \\
\hline 14 & 5.8 & 507.5 & & \\
\hline 15 & 5.8 & 507.5 & & \\
\hline 16 & 5.8 & 507.5 & & \\
\hline
\end{tabular}

\section{Method application on beverage product samples}

A total of five samples of beverage products with the same batch number were determined in terms of sodium benzoate and citric acid levels. A total of $0.1 \mathrm{~mL}$ of each sample solution was introduced into a $10 \mathrm{~mL}$ measuring flask and $0.1 \mathrm{~N} \mathrm{HCl}$ was added. After that, the absorbance of solutions were measured by the spectrophotometer and the data obtained were processed by chemometric model of PCR and PLS-1 which had been developed and validated.

\section{Data Analysis}

The linearity value was calculated based on linear regression method in the terms of square of the correlation coefficient $\left(R^{2}\right)$ between the concentration of sodium benzoate and citric acid added and the predicted concentration in the model. Method accuracy was indicated by the percentage of recovery value between standard concentrations added and measured concentrations using analytical methods and precision values were evaluated by the \% RSD value of the measured results obtained. LOD and LOQ were determined from the residual standard deviation and the intercept value on the linear calibration equation obtained. The LOD value was expressed as three times of the residual standard deviation and the LOQ value was expressed as ten times of the residual standard deviation on the measurement result. Levels of sodium benzoate and citric acid were measured from beverage products and were compared to the requirement limits of the use of both compounds in beverage products (Varzakas and Tzia, 2015).

\section{RESULTS AND DISCUSSION}

\section{Profile of UV spectra standard solutions}

The UV absorbance of each standard solution of sodium benzoate and citric acid with $0.1 \mathrm{~N} \mathrm{HCl}$ solution as a blank were measured using a spectrophotometer in the wavelength range of $190 \mathrm{~nm}$ to $400 \mathrm{~nm}$ (Figure 2). The UV absorbance profile of both compounds seemed to be overlap in the range of $190 \mathrm{~nm}$ to $300 \mathrm{~nm}$ wavelength range with the maximum absorbance of sodium benzoate at $229 \mathrm{~nm}$ and citric acid at $208 \mathrm{~nm}$. The overlapping spectra caused problems in the analysis of both compounds 
simultaneously using conventional spectrophotometry without any separation steps. The determination of each compound in a mixture solutions that have overlapping spectra could only be solved by chromatographic separation methods or using a method of spectrophotometry combined with chemometrics approaches (Miller and Miller, 2010). This method could be used to determine the level of compound having spectrum overlap profile because it could separate the information with the noise part of the obtained data and could minimize the occurrence of error on the calibration model (Ragupathy and Arcot, 2013).

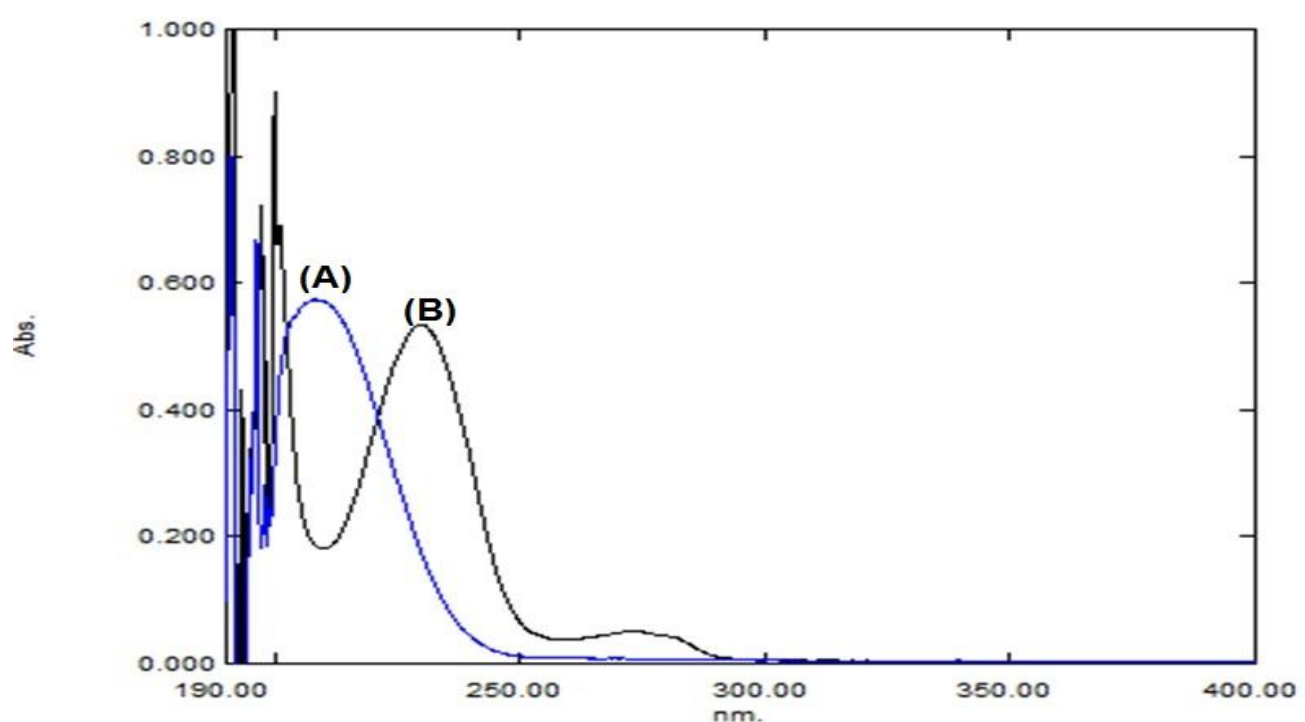

Figure 2. Absorption profile of citric acid solution $550.0 \mu \mathrm{g} / \mathrm{mL}(\mathrm{A})$ and sodium benzoate $5.0 \mu \mathrm{g} / \mathrm{mL}(\mathrm{B}) \mathrm{in}$ $0.1 \mathrm{~N} \mathrm{HCl}$ at wavelength of $190 \mathrm{~nm}$ to $400 \mathrm{~nm}$.

\section{Development of chemometric models}

The development of a spectrophotometric method combined with a chemometric model was performed using a standard solution mixture of training sets and test sets that were constructed based on CCD calculation. CCD was built in order to get more information from smaller number of experiment. Absorbance values were recorded and processed at the wavelength range that gave the absorption value at $200 \mathrm{~nm}$ to $300 \mathrm{~nm}$ because in those wavelengths contained the information of spectrophotometric responses from each compound. Wavelengths below $200 \mathrm{~nm}$ were not selected because there were a lot of noise as well as at wavelengths above $300 \mathrm{~nm}$ no visible absorption or absorbance value information was required. The absorbance of training data sets resulted in the optimum wavelength used were $235 \mathrm{~nm}$ to $250 \mathrm{~nm}$ for sodium benzoate and $220 \mathrm{~nm}$ to $240 \mathrm{~nm}$ for citric acid with the optimum principal components (PCs) value selected was 6 (PCR) and 4 (PLS-1) for sodium benzoate and PC 2 (PCR and PLS-1) for citric acid. The wavelength range and PC values were selected because they meet the statistical parameters criteria of model validation internally with the LOO-CV method (Table II) in the form of small values of RMSEC and RMSEP and the value of $\mathrm{r}^{2}$ seemed to near of 1 which illustrated better predictive capabilities with prediction error numbers which was getting smaller (Esbensen et al., 2004). Model validation using an external test set was conducted in order to evaluate the ability of the model to predict the measurement results of the selected calibration model. External validation of the model (Table III) was found to be good enough, especially on the results of citric acid measurements described by the predicted level by the model compared to the measured compound level expressed as the average of percentage recovery value. 
Table II. Statistical parameters of optimum model for PCR and PLS-1

\begin{tabular}{|c|c|c|c|c|}
\hline \multirow{2}{*}{ Parameters } & \multicolumn{2}{|c|}{ PCR } & \multicolumn{2}{|c|}{ PLS-1 } \\
\hline & Sodium Benzoate & Citric Acid & Sodium Benzoate & Citric Acid \\
\hline$\lambda(\mathbf{n m})$ & $235-250$ & $220-240$ & $235-250$ & $220-240$ \\
\hline PCs & 6 & 2 & 4 & 2 \\
\hline RMSEC & 0.124 & 13.044 & 0.142 & 13.044 \\
\hline RMSEP & 0.248 & 14.924 & 0.232 & 14.925 \\
\hline$r^{2}$ model & 0.991 & 0.995 & 0.988 & 0.995 \\
\hline
\end{tabular}

Table III. The recovery value of the test sets measurements using PCR and PLS-1 models

\begin{tabular}{cccccc}
\hline \multirow{2}{*}{$\begin{array}{c}\text { Mixture } \\
\text { Solutions }\end{array}$} & \multicolumn{2}{c}{ PCR } & & \multicolumn{2}{c}{ PLS-1 } \\
\cline { 2 - 3 } \cline { 2 - 3 } \cline { 5 - 6 } & Sodium Benzoate & Citric Acid & & Sodium Benzoate & Citric Acid \\
\hline $\mathbf{1}$ & 123.26 & 103.70 & & 126.11 & 103.70 \\
$\mathbf{3}$ & 123.64 & 103.08 & & 126.86 & 103.08 \\
$\mathbf{4}$ & 121.38 & 99.69 & & 125.59 & 99.69 \\
$\mathbf{5}$ & 116.86 & 98.06 & & 121.06 & 98.06 \\
$\mathbf{6}$ & 114.39 & 98.85 & & 112.82 & 98.85 \\
$\mathbf{7}$ & 110.40 & 97.15 & & 108.68 & 97.15 \\
$\mathbf{8}$ & 104.29 & 99.10 & & 104.01 & 99.09 \\
$\mathbf{9}$ & 127.20 & 97.99 & & 126.57 & 97.98 \\
$\mathbf{1 0}$ & 121.53 & 94.82 & & 127.42 & 94.82 \\
\hline Average & 113.94 & 98.36 & 115.85 & 98.35 \\
\% RSD & 117.69 & 99.08 & & 119.49 & 99.08 \\
\hline
\end{tabular}

\section{Validation of analytical method}

Validation of analytical method was performed to prove that the analytical parameters met the requirements for their purposes (Borman and Elder, 2017). The parameters that were evaluated include of linearity and range, accuracy, precision, LOD and LOQ. The linearity assay was conducted at five concentration of standard mixed solution and it was measured in three replicate each of them resulted in the value of $R^{2}$ for the two compounds analyzed were greater than 0.9 in the range of sodium benzoate concentration of 2.0-8.0 $\mu \mathrm{g} /$ and citric acid 200.0-800.0 $\mu \mathrm{g} / \mathrm{mL}$ (Figure 3). These results illustrated a linear relationship between the concentration measured and the predicted concentrations by the chemometrics model PCR and PLS-1. 

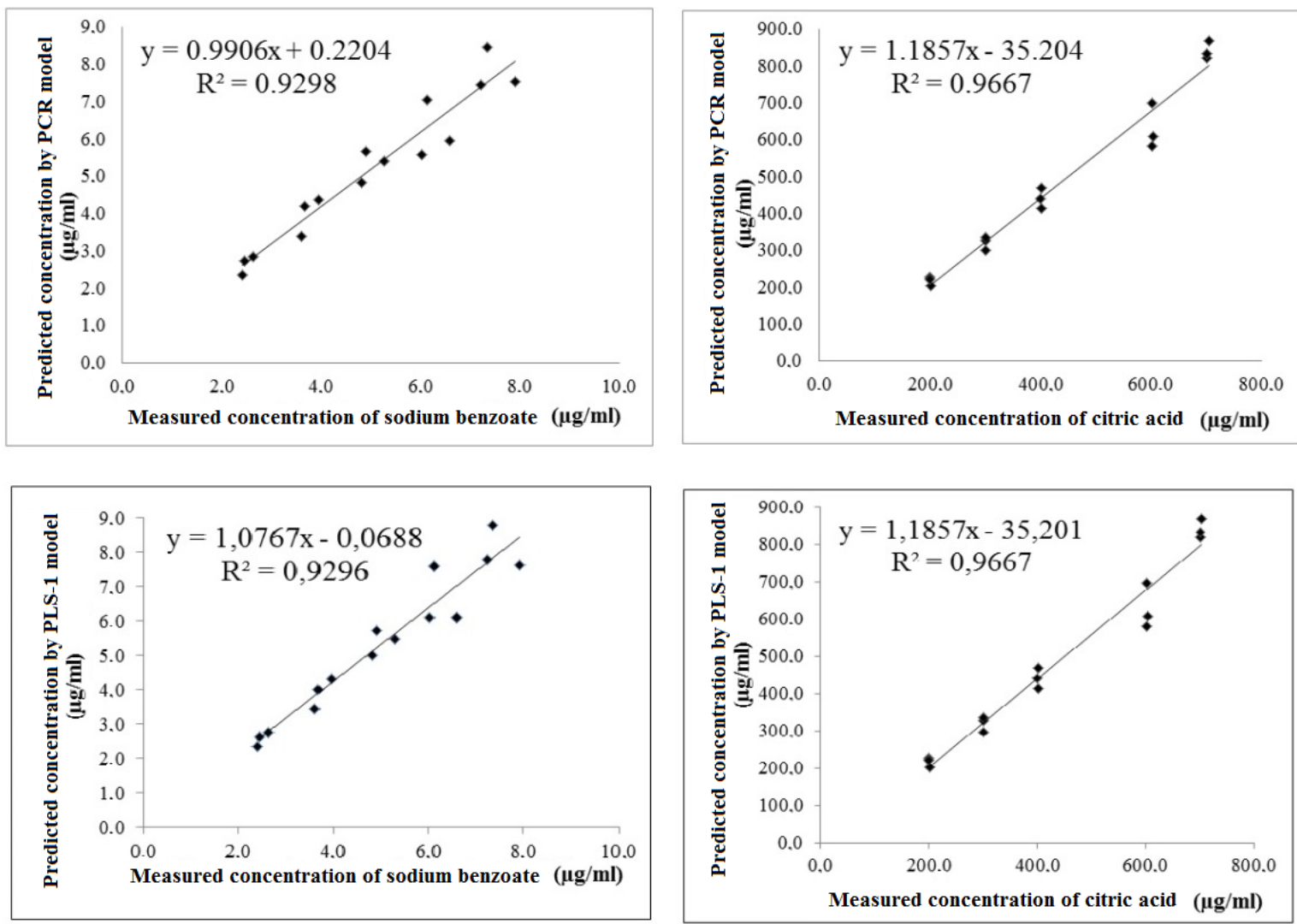

Figure 3. Standard mixture calibration curve of sodium benzoate and citric acid that performed by PCR and PLS-1 chemometric models

Accuracy and precision evaluations for both intra-day and inter-day were presented in Table IV. The average recovery rate of sodium benzoate was roughly $100.0 \%$ to $117.0 \%$ for the PCR and $102.0 \%$ to $122.0 \%$ for the PLS- 1 . Meanwhile, the average recovery rate of citric acid ranged between $98.0 \%$ to $106.0 \%$ for the PCR and $99.0 \%$ to $106.0 \%$ for the PLS-1. Intra-day and inter-day precision values expressed as percentage of RSD for sodium benzoate tend to be larger when compared with citric acid. The results of the evaluation of the accuracy and precision parameters (Table IV) showed that the accuracy and precision for the measurement of citric acid tend to be better than sodium benzoate. The result of calculation of validation parameter in terms of LOD and LOQ values for PCR and PLS-1 model measurement of sodium benzoate were $1.6 \mu \mathrm{g} / \mathrm{mL}$ and $5.3 \mu \mathrm{g} / \mathrm{mL}$ respectively. The LOD and LOQ values obtained for citric acid were $111.2 \mu \mathrm{g} / \mathrm{mL}$ and $370.7 \mu \mathrm{g} / \mathrm{mL}$ respectively.

\section{Method Applications for beverage product samples}

Simultaneous determination of sodium benzoate and citric acid using spectrophotometric method with PCR and PLS-1 chemometrics approach was applied to five samples of beverage products. The average measurement results (Table V) were obtained that a range of levels for sodium benzoate between $0.04 \%$ to $0.05 \%$ and citric acid $3.06 \%$ to $3.25 \%$. The results of measurements with both models PCR and PLS-1 gave the same results for five beverage products with the same batch number. These results indicated that the content of both food additives were still eligible for the product being tested. The maximum level as an additive for sodium benzoate was less than $5.17 \%$ and for citric acid less than 10\% (Varzakas and Tzia, 2015). 
Table IV. The results of accuracy and precision assays for sodium benzoate and citric acid

\begin{tabular}{|c|c|c|c|c|c|c|c|c|}
\hline \multirow{4}{*}{ Sample } & \multicolumn{8}{|c|}{ Recovery (\%) } \\
\hline & \multicolumn{4}{|c|}{ Intra-day } & \multicolumn{4}{|c|}{ Inter-day } \\
\hline & \multicolumn{2}{|c|}{ PCR } & \multicolumn{2}{|c|}{ PLS-1 } & \multicolumn{2}{|c|}{ PCR } & \multicolumn{2}{|c|}{ PLS-1 } \\
\hline & $\begin{array}{c}\text { Sodium } \\
\text { Benzoate }\end{array}$ & $\begin{array}{l}\text { Citric } \\
\text { Acid }\end{array}$ & $\begin{array}{c}\text { Sodium } \\
\text { Benzoate }\end{array}$ & $\begin{array}{l}\text { Citric } \\
\text { Acid }\end{array}$ & $\begin{array}{c}\text { Sodium } \\
\text { Benzoate }\end{array}$ & $\begin{array}{l}\text { Citric } \\
\text { Acid }\end{array}$ & $\begin{array}{c}\text { Sodium } \\
\text { Benzoate }\end{array}$ & $\begin{array}{l}\text { Citric } \\
\text { Acid }\end{array}$ \\
\hline \multicolumn{9}{|l|}{$(80 \%)$} \\
\hline 1 & 125.09 & 92.67 & 127.14 & 102.58 & 129.47 & 104.50 & 106.12 & 90.06 \\
\hline 2 & 104.84 & 104.65 & 107.23 & 92.56 & 99.15 & 90.72 & 105.44 & 106.86 \\
\hline 3 & 123.38 & 102.69 & 123.17 & 104.53 & 106.71 & 100.66 & 123.85 & 103.8 \\
\hline $\bar{x}$ & 117.77 & 100.00 & 119.18 & 99.89 & 111.78 & 98.63 & 111.81 & 100.24 \\
\hline $\begin{array}{c}\% R S D \\
(100 \%)\end{array}$ & 9.53 & 6.42 & 8.84 & 6.43 & 14.12 & 7.21 & 9.34 & 8.92 \\
\hline 1 & 114.55 & 95.06 & 129.74 & 100.22 & 115.62 & 105.05 & 118.62 & 92.97 \\
\hline 2 & 113.44 & 104.62 & 119.51 & 94.97 & 108.51 & 93.49 & 120.22 & 102.48 \\
\hline 3 & 117.76 & 100.32 & 119.15 & 104.50 & 114.93 & 98.69 & 113.47 & 104.49 \\
\hline$\overline{\boldsymbol{x}}$ & 115.25 & 100.00 & 122.8 & 99.91 & 113.02 & 99.08 & 117.44 & 99.98 \\
\hline $\begin{array}{c}\% R S D \\
(120 \%)\end{array}$ & 1.95 & 4.79 & 4.90 & 4.79 & 3.47 & 5.84 & 3.00 & 6.15 \\
\hline 1 & 100.07 & 104.07 & 110.27 & 104.63 & 104.65 & 108.80 & 108.04 & 102.33 \\
\hline 2 & 104.53 & 109.48 & 108.78 & 104.10 & 90.41 & 102.77 & 97.57 & 102.79 \\
\hline 3 & 108.31 & 104.71 & 107.57 & 109.40 & 105.78 & 102.35 & 100.7 & 108.33 \\
\hline$\overline{\boldsymbol{x}}$ & 104.30 & 106.09 & 108.87 & 106.00 & 100.28 & 104.97 & 102.1 & 104.48 \\
\hline$\% R S D$ & 3.95 & 2.79 & 1.24 & 2.79 & 8.54 & 3.32 & 5.26 & 3.19 \\
\hline
\end{tabular}

Table V. Average of sodium benzoate and citric acid concentrations in beverage product samples tested

\begin{tabular}{cccccc}
\hline \multirow{2}{*}{ Sample } & \multicolumn{3}{c}{ Concentrations (\% w/v \pm RSD) } \\
\cline { 2 - 3 } \cline { 2 - 3 } \cline { 5 - 6 } & Sodium Benzoate & Citric Acid & & Sodium Benzoate & Citric Acid \\
\hline & $0.05 \pm 0.02$ & $3.25 \pm 0.08$ & & $0.04 \pm 0.05$ & $3.25 \pm 0.08$ \\
2 & $0.05 \pm 0.03$ & $3.06 \pm 0.03$ & & $0.04 \pm 0.04$ & $3.06 \pm 0.03$ \\
3 & $0.05 \pm 0.02$ & $3.24 \pm 0.04$ & & $0.05 \pm 0.02$ & $3.24 \pm 0.04$ \\
4 & $0.05 \pm 0.04$ & $3.18 \pm 0.07$ & & $0.05 \pm 0.03$ & $3.17 \pm 0.07$ \\
5 & $0.05 \pm 0.05$ & $3.17 \pm 0.02$ & & $0.05 \pm 0.03$ & $3.17 \pm 0.02$ \\
\hline
\end{tabular}




\section{CONCLUSION}

Spectrophotometric method with chemometrics approach has been successfully developed by using the optimum wavelength of $235 \mathrm{~nm}$ to $250 \mathrm{~nm}$ for sodium benzoate and $220 \mathrm{~nm}$ to $240 \mathrm{~nm}$ for citric acid with the selected optimum principal components (PCs) value were 6 (PCR) and 4 (PLS-1) for sodium benzoate and PCs 2 (PCR and PLS-1) for citric acid. Analytical method validation gave a good linearity for both compounds with suitable accuracy and precision for citric acid determination. The developed methods could be applied for analysis of sodium benzoate and citric acid contents in beverage products.

\section{ACKNOWLEDGMENTS}

Acknowledgments were given to the Pharmaceutical Chemistry Laboratory, Department of Pharmacy, Faculty of Health Sciences and Inorganic Chemistry Laboratory, Faculty of Mathematics and Natural Sciences, Jenderal Soedirman University for supporting research facilities.

\section{REFERENCES}

Abd-AlGadir, M., Ihaimer, M., Elkhier, M.S., Idris, O., 2009. Effect of benzoic acid and combination of benzoic with citric acid as food additives on the renal function of experimental rats. Asian $J$. Clin. Nutr. 1, 83-87.

Ayorinde, F.O., Bezabeh, D.Z., Delves, I., 2003. Preliminary investigation of the simultaneous detection of sugars, ascorbic acid, citric acid, and sodium benzoate in non-alcoholic beverages by matrix-assisted laser desorption/ionization time-of-flight mass spectrometry. Rapid Commun. Mass Spectrom. 17, 1735-1742.

Bezerra, M.A., Santelli, R.E., Oliveira, E.P., Villar, L.S., Escaleira, L.A., 2008. Response surface methodology (RSM) as a tool for optimization in analytical chemistry. Talanta 76, 965-977.

Borman, P., Elder, D., 2017. Q2(R1) Validation of Analytical Procedures, in: ICH Quality Guidelines. Wiley-Blackwell, pp. 127-166.

Brereton, R.G., 2000. Introduction to multivariate calibration in analyticalchemistry. Analyst 125, $2125-2154$.

Brima, E., Abbas, A., 2014. Determination of Citric acid in Soft drinks, Juice drinks and Energy drinks using Titration. Int J Chem Stud 1, 30-34.

Chen, X., Lv, Q., Liu, Y., Deng, W., 2015. Effects of the food additive, citric acid, on kidney cells of mice. Biotech. Histochem. Off. Publ. Biol. Stain Comm. 90, 38-44.

Chen, X., Lv, Q., Liu, Y., Deng, W., 2014. Study on injury effect of food additive citric acid on liver tissue in mice. Cytotechnology 66, 275-282.

Ciriminna, R., Meneguzzo, F., Delisi, R., Pagliaro, M., 2017. Citric acid: emerging applications of key biotechnology industrial product. Chem. Cent. J. 11.

El-Zaher, A.A., Elkady, E.F., Elwy, H.M., Saleh, M.A.E.M., 2017. Simultaneous spectrophotometric determination of glimepiride and pioglitazone in binary mixture and combined dosage form using chemometric-assisted techniques. Spectrochim. Acta. A. Mol. Biomol. Spectrosc. 182, $175-182$.

Esbensen, K.H., Guyot, D., Westad, F., Houmoller, L.P., 2004. Multivariate Data Analysis: In Practice : an Introduction to Multivariate Data Analysis and Experimental Design, 5th ed. Oslo, Norway: CAMO, 19-695.

Faber, K., Kowalski, B.R., 1997. Critical evaluation of two F-tests for selecting the number of factors in abstract factor analysis. Anal. Chim. Acta 337, 57-71.

Geladi, P., 2003. Chemometrics in spectroscopy. Part 1. Classical chemometrics. Spectrochim. Acta Part B At. Spectrosc. 58, 767-782. 
Grembecka, M., Baran, P., Błażewicz, A., Fijałek, Z., Szefer, P., 2014. Simultaneous determination of aspartame, acesulfame-K, saccharin, citric acid and sodium benzoate in various food products using HPLC-CAD-UV/DAD. Eur. Food Res. Technol. 238, 357-365.

Keshavarz, M.H., Gharagheizi, F., Shokrolahi, A., Zakinejad, S., 2012. Accurate prediction of the toxicity of benzoic acid compounds in mice via oral without using any computer codes. $J$. Hazard. Mater. 237, 79-101.

Marini, F., 2016. Chemometrics, in: Encyclopedia of Food and Health. Academic Press, Oxford, pp. $1-9$.

Miller, J., Miller, J.C., 2010. Statistics and Chemometrics for Analytical Chemistry, 6 edition. ed. Pearson Education Canada, Harlow.

Patel, N.S., Nandurbarkar, V.P., Patel, A.J., Patel, S.G., 2014. Simultaneous spectrophotometric determination of Celecoxib and Diacerein in bulk and capsule by absorption correction method and chemometric methods. Spectrochim. Acta. A. Mol. Biomol. Spectrosc. 125, 46-52.

Penniston, K.L., Nakada, S.Y., Holmes, R.P., Assimos, D.G., 2008. Quantitative Assessment of Citric Acid in Lemon Juice, Lime Juice, and Commercially-Available Fruit Juice Products. $J$. Endourol. 22, 567-570.

Phechkrajang, C., Sribunruang, S., Thitipong, A., Jarusintanakorn, S., Sratthaphut, L., Nacapricha, D., Wilairat, P., 2011. Chemometrics-assisted UV spectrophotometric method for determination of acetaminophen and chlorzoxazone in tablets. Mahidol Univ J Pharm Sci 38, 23-33.

Ragupathy, V., Arcot, S., 2013. Simultaneous Spectrophotometric Determination Of Diacerein And Celecoxib In Capsules by Chemometric Methods. Int. Res. J. Pharm. 4, 229-233.

Ren, Y.-F., Amin, A., Malmstrom, H., 2009. Effects of tooth whitening and orange juice on surface properties of dental enamel. J. Dent. 37, 424-431.

Shahmohammadi, M., Javadi, M., Nassiri-Asl, M., 2016. An Overview on the Effects of Sodium Benzoate as a Preservative in Food Products. Biotechnol. Health Sci. 3, e35084.

Shu, Y., Yu, B., He, J., Yu, J., Zheng, P., Yuan, Z., Chen, D., Mao, X., 2016. Excess of dietary benzoic acid supplementation leads to growth retardation, hematological abnormality and organ injury of piglets. Livest. Sci. 190, 94-103.

Sratthaphut, L., Ruttanakorn, K., 2015. Chemometrics-Assisted UV Spectrophotometric Method for Determination of Metformin Hydrochloride and Glyburide in Pharmaceutical Tablets. Presented at the Advanced Materials Research, Trans Tech Publ, pp. 164-167.

Varmuza, K., Filzmoser, P., Hilchenbach, M., Krüger, H., Silén, J., 2014. KNN classification evaluated by repeated double cross validation: Recognition of minerals relevant for comet dust. Chemom. Intell. Lab. Syst. 138, 64-71.

Varzakas, T., Tzia, C., 2015. Handbook of Food Processing: Food Safety, Quality, and Manufacturing Processes. CRC Press.

Wasito, H., Buranaphalin, S., Sratthaphut, L., Suntornsuk, L., Wilairat, P., Phechkrajang, C.M., 2018. Comparison of Mean Centering of Ratio Spectra Based Spectrophotometric Approach and HPLC Method for Quantitative Determination of Pirenoxine in the Presence of Methylparaben and Propylparaben. Indian J. Pharm. Educ. Res. 52, 284-292.

Wasito, H., Phechkrajang, C., 2015. Validated visible spectrophotometry for quantitative analysis of pirenoxine in the presence of paraben preservatives in eye drop preparations, in: 2015 4th International Conference on Instrumentation, Communications, Information Technology, and Biomedical Engineering (ICICI-BME). Presented at the 2015 4th International Conference on Instrumentation, Communications, Information Technology, and Biomedical Engineering (ICICI-BME), pp. 327-331. 